\title{
Stock Allocation in Turkish Capital Markets: Industry and Firm Level Perspectives
}

\section{Ozlem KUTLU FURTUNA}

\author{
PhD Center for Finance, Governance and Sustainability (CFGS), Business Administration Department, Yildiz Technical
} University, Turkey

\begin{abstract}
Investors' trading patterns has been an intensively researched topic in emerging markets depending on their significant role and power in the capital markets. This paper provides what global and domestic factors have driven the stock allocation of investors in Turkey and how has the crisis changed investors' attitude toward stock allocation between the years 2006 and 2016. Year-end stock allocation data are obtained from the Central Securities Depository Institution of Turkey. Stock allocation has been investigated mainly in terms of the domestic and foreign stock investments. A detailed classification of investors as individual and institutional investors in terms of investment funds, corporate and investment trusts with firm and industry levels has also been evaluated. The variations on stock allocation has been examined in BIST Industrials, Financials and Services Industries. Additionally, this paper gives an insight about the firm and industry level stock allocation in Turkish Capital Markets considering the responsible stockholders. Corporate governance practices are considered to be strengthened with the growing role of institutional investors in the financial system, which provide insights about the investor profile of BIST Corporate Governance Index in the related period.
\end{abstract}

Keywords: stock allocation, institutional investors, industrial classification, corporate governance, responsible stockholder, Turkey

\section{Introduction}

The last two decades have witnessed an enormous trend allowing foreign investors to invest in the stock securities of domestic firms in many emerging countries and there have been various studies undertaken to investigate this hot topic. Turkey has become one of the focuses of these inquiries. Turkish government has made several amendments on that respect. Turkey has introduced auto enrolment in private pension system beginning from 1 January 2017 and another attempt for Turkey is the Turkish Wealth Fund which has been established in 2016 for effectively managing the selected assets. This fund is expected to contribute to the development of the domestic capital markets. All these initiatives have a significant role to gain attendance of foreign investors.

According to Turkish Capital Markets Association Report (TCMA Report, 2017), financial savings in Turkey decreased by $6 \%$ to US $\$ 644$ billion from US\$ 685 billion in 2016. Although the total savings increased by $13.8 \%$ in Turkish Lira terms, the deterioration of the Turkish Lira versus the US Dollar depressed the financial savings. Share of stocks in investors' portfolio constitute only $9 \%$ of financial savings. In that respect, total number of identified and active accounts have declined from 1,059,313 units in 2015 to over 1,040,794 units as of the end of 2016 with a decrease of $1.7 \%$. The portfolio size of active accounts has declined from US\$ 78 million in 2015 to US\$ 70 million as of the end of December, 2016 with a decrease of $11 \%$. In the same report investors are first segregated as domestic and foreign investors. The portfolio size of stocks allocated by foreign investors are US\$ 48 million in 2015; the portfolio size of this decrease to US\$ 40 million in December, 2016 with a 17 \% (TCMA 2017, p.38). Second portfolio segregation shed light on the individual and institutional stock holders. While the domestic individual investors constitutes nearly the half of all individual stockholders, as a result of the low amount of foreign individual investors, total individual investors constitutes only $19 \%$ of total investors. This gives the dominance of institutional investors $81 \%$ of total portfolio in 2016. These numerical expressions indicate that in emerging markets, foreign institutional investors are more sophisticated and have an information advantage of global information (Kim and Yi, 2015). 
As financial development is strongly correlated with the capital allocation (Levine and King, 1993), through long-term view of institutional investors may make a significant contribution to the growth of capital markets. Ferreira and Matos (2008) study the role of investors' profile around the world using a detailed data set of stock holdings from 27 countries between the years 2000 and 2005. They state that all institutional investors eager to hold share a preference for the stock of large firms in countries with strong disclosure standards. However, while foreign institutional investors prefer to invest in firms that are cross-listed on a U.S. exchange, domestic institutions underweight these same stocks.

As in the previous studies, domestic and foreign investors typically include institutions, corporations, investment trusts, other institutions and individual investors. That segregation points out the distinction between the sophisticated and informed institutional investors and the less sophisticated and less informed non-institutional investors, like individual stockholders (Covrig et al., 2006).

Industry characteristics may also effect the stock preferences of the investors. Zou et al. (2016) study the stock preferences of domestic and foreign investors and exhibit that foreign institutional investors prefer to invest in sectors such as financial, transportation, professional services, and technology in Chinese capital markets. This paper gives insights about firm and industry level perspectives since the effects of institutional investors can be observed both in capital markets and directly the growth of the firm and hence the growth of industry incorporating in the economy (Railo, 2000).

Brancato (1997) indicates for maximizing shareholder value, corporate governance is essential for institutional investors. Additionally, these investors have to take responsibility not as a trader but as a firm owner. From that point of view, this paper gives a view of what attracts foreign - domestic and individual - institutional investors to hold stocks in Turkish capital markets. What extent the industrial breakdown, strong governance indicators and sustainable firms have been preferred for the stockholders in Turkish Capital Markets? Stockholders are eager to focus on investing in specific industries which accomplish their ultimate goal of shareholders' wealth maximization. This paper also gives an insight about the domestic, foreign, individual and several types of institutional investors' attitudes on investing strategies on industry.

The following section provides the yearly breakdown of stockholders in Turkey, followed by a section describing the database employed. The following sections contains interrelationship among stock allocation, industrial characteristics and responsible investments in Turkish capital markets. The final section concludes the paper.

\section{Breakdown of Stockholders in Turkish Capital Markets}

Data has been taken from Turkish Capital Markets Association (TCMA) and Central Securities Depository of Turkey (MKK). Additionally, the database of Borsa Istanbul (BIST) and BIST Public Disclosure Platform (KAP) are used for the determination of industry breakdown. Since the stockholders allocation data can be obtained only in the form of yearly end, the sample is comprised of all stocks listed on BIST between the years 2006 and 2016. The final sample is made up of 252 stocks resulting in a total of 2.772 stock-year observations during eleven years.

In line with investor classification of MKK, which provide categories of domestic and foreign stockholders in addition to the individual and institutional stockholders. Institutional stockholders are classified as investment funds, corporates, investment trusts and others. Table 1 exhibits the breakdown of the data and variables used in that study. Fractional institutional ownership represents the ratio of number of shares held by institutional investors to the numbers of shares outstanding following the studies of (Falkenstein 1996, Nofsinger and Sias, 1999).

\section{Table 1: Breakdown of Stockholders}

Domestic Investment Fund $\quad \begin{aligned} & \text { The ratio of the number of shares that are held by domestic investment funds in terms of mutual } \\ & \text { funds and private pension plans to total shares outstanding at year } t \text { for stock } i\end{aligned}$

Domestic Corporate The ratio of the number of shares that are held by domestic corporates in terms of banks, financial intermediaries and corporations to total shares outstanding at year $t$ for stock $i$ 
Domestic Investment Trusts The ratio of the number of shares that are held by investment trusts to total shares outstanding at year $t$ for stock $i$

Domestic Other Institutions The ratio of the number of shares that are held by domestic other institutions in terms of charities, associations and cooperatives to total shares outstanding at year $t$ for stock $i$

Foreign Investment Fund The ratio of the number of shares that are held by foreign investment funds in terms of mutual funds and private pension plans to total shares outstanding at year $t$ for stock $i$

Foreign Corporate

Foreign Other Institutions

Institutional

Individual
The ratio of the number of shares that are held by foreign corporates in terms of banks, financial intermediaries and corporations to total shares outstanding at year $t$ for stock $i$

The ratio of the number of shares that are held by foreign other institutions in terms of charities, associations and cooperatives to total shares outstanding at year $t$ for stock $i$

The ratio of the number of shares that are held by institutional investors to total shares outstanding at year $t$ for stock $i$

The ratio of the number of shares that are held by individual investors to total shares outstanding at year $t$ for stock $i$

Table 2 exhibits yearly stock allocation in terms of fractional domestic, foreign, individual and institutional investors' ownership. As foreign and institutional investors have a predominant share in the total stock portfolio, movements of the BIST index are mainly driven by stock transactions on behalf of the foreign institutional investors.

On the other hand, the share of individual investors in the stock market is very limited in comparison to the other stock holders. These results evidence that the stock ownership is not the preferred way of domestic investors in Turkey and Turkish individual investors seem to be reluctant to invest in capital markets.

Table 2: Yearly Stock Allocation of Investors in Turkish Capital Markets (\%)

\begin{tabular}{|c|c|c|c|c|c|c|c|c|}
\hline Year & Domestic & Foreign & Individual & $\begin{array}{l}\text { Institutio } \\
\text { Fund }\end{array}$ & Corp & Trust & Other & Total \\
\hline 2006 & 0.3037 & 0.6963 & 0.1978 & 0.3108 & 0.4664 & 0.0036 & 0.0214 & 0.8022 \\
\hline 2007 & 0.2648 & 0.7352 & 0.1516 & 0.3453 & 0.4803 & 0.0000 & 0.0228 & 0.8484 \\
\hline 2008 & 0.3105 & 0.6895 & 0.1727 & 0.4900 & 0.3147 & 0.0030 & 0.0197 & 0.8273 \\
\hline 2009 & 0.3101 & 0.6899 & 0.1961 & 0.5080 & 0.2733 & 0.0021 & 0.0205 & 0.8039 \\
\hline 2010 & 0.3169 & 0.6831 & 0.1926 & 0.4897 & 0.3013 & 0.0016 & 0.0148 & 0.8074 \\
\hline 2011 & 0.3387 & 0.6613 & 0.2079 & 0.4871 & 0.2857 & 0.0023 & 0.0170 & 0.7921 \\
\hline 2012 & 0.3048 & 0.6952 & 0.1692 & 0.5111 & 0.3028 & 0.0015 & 0.0154 & 0.8308 \\
\hline 2013 & 0.3360 & 0.6640 & 0.1777 & 0.5097 & 0.2851 & 0.0013 & 0.0262 & 0.8223 \\
\hline 2014 & 0.3258 & 0.6742 & 0.1649 & 0.5070 & 0.3095 & 0.0011 & 0.0175 & 0.8351 \\
\hline 2015 & 0.3529 & 0.6471 & 0.1798 & 0.4573 & 0.3460 & 0.0010 & 0.0158 & 0.8202 \\
\hline 2016 & 0.3457 & 0.6543 & 0.1791 & 0.4472 & 0.3593 & 0.0016 & 0.0128 & 0.8209 \\
\hline
\end{tabular}




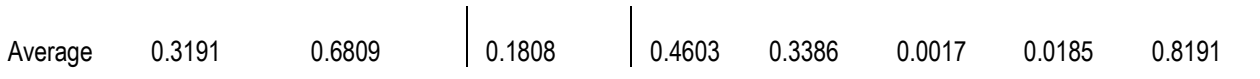

After 2008 global financial crises, a decline has been observed in terms of the foreign stockholders with the average falling to $68.95 \%$. Additionally, this variable have declined to $65.43 \%$. This exhibits that more robust policies should be formulated to attract foreign portfolio investors for attaining a suitable investment climate in the following years. Furthermore, Huang and Shiu (2005) posit that foreign investors can actually be better informed than domestic investors.

A current work belongs to Ferreira et al. (2017) who investigate a list of all firms covered in the Datastream and WorldScope database for 32 countries between the years 2000 and 2010. They state that domestic investors on average seem to trade in countries with high levels of corruption, weak investor protection and less efficient stock markets. They interpret that finding as where information asymmetry is likely to be more severe, increases in the holdings of domestic investors are followed by higher future returns, while increases in holdings of foreign investors are followed by lower stock returns. From this perspective, after 2008 global financial turmoil, an increase has been observed in domestic and individual investors' stockholders in Turkish capital markets.

The average values of institutional stockholders which is documented to be the dominant investment style in terms of investment horizon is reported to be an average of $81.91 \%$ for the eleven year period between 2006 and 2016. Yearly institutional stockholders follow the same pattern, the average values have been declined in recent years.

\section{Industry Characteristics and Stock Allocation}

Apart from the macroeconomic factors, firm specific determinants and additionally industry characteristics may influence the investment opportunities and their expected returns closely add value the investment strategies of stockholders. Table 3 gives an insight about whether the industrial breakdown differ in stock allocation decisions in Turkish capital markets in the related period.

Foreign and institutional stockholders have also seen a predominant effect rather than domestic and individual stockholders for all types of industries. Moreover, BIST Services industry and Retail Service sub industry seem to have the highest average institutional stockholders as well. This may be the result of having more growth prospects in Turkey in the related industries. This similar pattern has also seen in that same industry and sub-industry having the highest foreign stockholders.

Following the BIST Services industry, BIST Financials industry and Banks sub industry have the second highest average foreign and institutional stockholders ownership. Stock allocation has followed a different trend in sub industries of that industry. For instance, in Textile and Other sub industries have the highest average domestic and individual stockholders rather than the all sub industries.

Real Estate Investment Trusts (REITs) have been more popular in Turkey and attract several investors in recent years. As an emerging economy, Technology industry has been still in the relatively early stage in Turkey which is expected to drive future growth.

Food, Beverage and Tobacco sub industry can be considered to be non-cyclical and regardless of the economic conditions, products and services may have a constant demand. Therefore, this industry may be considered as less volatile for investors. It is well known that Materials sub industry may be deeply cyclical closely tying with the low cost and high cost producers. In robust macro-economic conditions, investors can earn money however in downturns, the stocks can immediately fall.

Zou et al. (2016) state that domestic funds tend to over-invest in the following industries; Food Beverage and Tobacco, Household and Personal Products, Retailing, Pharmaceuticals, Biotechnology and Life Science, Health Care Equipment and Services, Software and Services, Commercial and Professional Services, and Consumer Services respectively

\section{Table 3: Industry based average Stock Allocation in Turkish Capital Markets}

\begin{tabular}{lllll} 
Industry Categories & Domestic & Foreign & Individual & Institutional \\
\hline BIST Financials & 0.2956 & 0.7044 & 0.1483 & 0.8517
\end{tabular}




$\begin{array}{lllll}\text { REITs } & 0.4213 & 0.5787 & 0.2379 & 0.7621 \\ \text { Holdings } & 0.3063 & 0.6937 & 0.2080 & 0.7920 \\ \text { Banks } & 0.2466 & 0.7534 & 0.1128 & 0.8872 \\ \text { BIST Industrials } & 0.4204 & 0.5796 & 0.2569 & 0.7431 \\ \text { Construction } & 0.6632 & 0.3368 & 0.4249 & 0.5751 \\ \text { Food, Beverage \& Tobacco } & 0.3304 & 0.6696 & 0.1661 & 0.8339 \\ \text { Chemicals } & 0.3411 & 0.6589 & 0.2356 & 0.7644 \\ \text { Materials } & 0.3687 & 0.6313 & 0.2231 & 0.7769 \\ \text { Paper Industry } & 0.7273 & 0.2727 & 0.2813 & 0.7187 \\ \text { Textile } & 0.8921 & 0.1079 & 0.6961 & 0.3039 \\ \text { Other Industrials } & 0.8693 & 0.1307 & 0.6975 & 0.3025 \\ \text { BIST Services } & 0.2517 & 0.7483 & 0.1475 & 0.8525 \\ \text { Electricity, Gas and Water } & 0.8535 & 0.1465 & 0.4114 & 0.5886 \\ \text { Technology } & 0.5809 & 0.4191 & 0.4920 & 0.5080 \\ \text { Retail Service } & 0.1580 & 0.8420 & 0.0826 & 0.9174 \\ \text { Construction Service } & 0.2519 & 0.7481 & 0.1435 & 0.8565 \\ \text { Hotels } & 0.9471 & 0.0529 & 0.5896 & 0.4104 \\ \text { Wholesale } & 0.4653 & 0.5347 & 0.1562 & 0.8438 \\ \text { Mining } & 0.5202 & 0.4798 & 0.4882 & 0.5118 \\ \text { Sports Services } & 0.8751 & 0.1249 & 0.6192 & 0.3808\end{array}$

Institutional investments heavily belong to BIST Financials and BIST Services industry. Taking everything into account, stock allocation on BIST is characterized by the dominance of the foreign institutional investors in the total equity portfolio. Domestic investors are characterized by the dominance of domestic individual investors but the share of them is very limited comparing with the other countries.

\section{Responsible Stockholders in Turkish Capital Markets}

European Fund Asset Management Organization (EFAMA Report, 2016) defines Responsible Investing as it is any method of selecting investments where both financial and non-financial considerations, such as standards, ethical or social norms are taken into consideration. From that respect, responsible stockholders have a tendency of the firms' social, environmental, governance considering the financial and economic issues. This term has become a significant part in the agenda in the last decade and BIST has made several amendments on that respect. Launching BIST Corporate Governance Index and BIST Sustainability Index has changed the way executives do business in Turkey and the attitudes of investors on that corporations.

BIST Corporate Governance Index has been launched in 2007 and aims to measure the price and return performances of companies traded on BIST with a corporate governance rating of minimum 7 over 10 as a whole and minimum of 6.5 for each main section. The score includes four main sections: Shareholders, Public Disclosure and Transparency, Stakeholders, Board of Directors. The corporate governance rating is determined by the rating institutions incorporated by $\mathrm{CMB}$ in its list of rating agencies as a result of their assessment of the company's compliance with the corporate governance principles as a whole. As at the end of 2016, there has been 50 firms listed on that index with six of them unlisted and one of them is nongovernmental organization.

BIST Sustainability Index has been launched which is comprised of the firms that are traded in BIST and have high sustainability performances in 2014 with 15 listed firms, 29 firms in 2015 and increasing to 43 firms in 2016.

Table 4: Stock Allocation on behalf of BIST Governance Index and BIST Sustainability Index

Panel A: BIST Governance Index 


\begin{tabular}{llll} 
Year & \# stock & Foreign & Institutional \\
\hline 2007 & 7 & 0.8037 & 0.8403 \\
2008 & 8 & 0.6799 & 0.8200 \\
2009 & 18 & 0.6732 & 0.8231 \\
2010 & 22 & 0.6938 & 0.8230 \\
2011 & 26 & 0.7226 & 0.8334 \\
2012 & 31 & 0.8017 & 0.9082 \\
2013 & 35 & 0.7275 & 0.8562 \\
2014 & 38 & 0.7144 & 0.8699 \\
2015 & 40 & 0.6935 & 0.8650 \\
2016 & 40 & 0.6903 & 0.8712 \\
Average & & 0.7201 & 0.8510
\end{tabular}

Panel B: BIST Sustainability Index

\begin{tabular}{llll} 
Year & \# stock & Foreign & Institutional \\
\hline 2014 & 9 & 0.7668 & 0.8778 \\
2015 & 15 & 0.6934 & 0.8496 \\
2016 & 19 & 0.7042 & 0.8478 \\
Average & & 0.7215 & 0.8584
\end{tabular}

Table 4 states stock allocation on behalf of BIST Governance Index and BIST Sustainability Index and gives an insight on the effect of responsible investments of firms on the investor portfolio in the related period. While the average of foreign stockholders is $68.09 \%$ that have been reported in Table 2, this variable has been increased to $72.01 \%$ in BIST well governed firms and $72.15 \%$ in firms listed on sustainability index. Findings reveal that foreign and institutional investors are eager to invest on stocks with better corporate governance and sustainability efforts.

According to McKinsey Company 2016 Global Investor Survey, institutional investors are found to prefer investing in firms with robust corporate governance practices. This paper try to provide additional insight by analyzing the percentage of foreign and institutional stockholders that are listed on the Corporate Governance Index and Sustainability Index.

It has to be stated that foreign institutional investors play crucial roles in bringing about change in corporate governance systems (Gillan and Starks, 2003) and sustainable firms attract more foreign investments than the others. Aggarwal et al. (2011) also evidence the significant role foreign institutions play in attaining the improvement of corporate governance practices as well. Furthermore, for Turkey Gurbuz et al. (2010) state that the impact of institutional investors has been more strongly pronounced on firms listed on the BIST corporate governance index than non-listed firms between the years 2005 and 2008.

\section{Conclusions}

Investors' place in the pattern of capital markets development has been a crucial debate in contemporary economics. This study gives and understanding of the interrelationship among stock allocation, industrial characteristics and responsible investments in Turkish capital markets. The investor profile on the BIST is characterized by the dominance of the domestic and institutional investors in the total equity portfolio. The share of domestic individual investors in the stock market is very limited in comparison to the other capital markets. Additionally, domestic investors are mainly composed of individuals with small portfolio holdings.

Industrial breakdown indicates that industry characteristics matter on the stock allocation and seem to be important drivers of investments in Turkish capital markets. Results suggest that there are significant differences in industry allocations between the domestic and foreign and individual and institutional stockholders in Turkey. Specifically, investments into the services industry and retail service sub industry seem to have the highest average institutional and foreign stockholders.

Findings reveal that foreign and institutional investors are eager to invest on stocks with better corporate governance and sustainability efforts. The stock allocation on responsible investments demonstrate that international portfolio investments by institutional investors is associated with enhanced monitoring leading to more effective corporate governance practices and sustainability efforts.

This paper gives an insight about the firm and industry level stock allocation in Turkish Capital Markets considering the responsible stockholders. The extent to what firm characteristics that the foreign and institutional investors preferred, will have significant implications for the ability of firms in emerging markets to raise capital and hence impact the growth of 
capital markets. Institutional Investors have an impulsive effect on the development of capital markets with professional portfolio management and with their ability of creating long term resources. Thus, policy makers have to take into account the dominance of these types of investors in the financial markets as they develop rules and regulations. Consequently, it would be interesting to explore the interrelatedness of investment characteristics and stock characteristics in terms of market value, profitability, and capital structure considering the governance and sustainability efforts of the firm around the emerging markets with a large dataset as a further study.

\section{References}

[1] Aggarwal, R., Erel, I., Ferreira, M. \& Matos, P. (2011). Does Governance Travel around the World? Evidence from Institutional Investors. Journal of Financial Economics. 100.1, 154-181.

[2] Brancato, C. (1997) Institutional Investors and Corporate Governance: Best Practices for Increasing Corporate Value, Chicago: Irwin Professional.

[3] Covrig, V. Lau, S.T. \& Ng, L. (2006). Do Domestic and Foreign Fund Managers have Similar Preferences for Stock Characteristics? A Cross-Country Analysis, Journal of International Business Studies, 1-45.

[4] European Fund Asset Management Organization, EFAMA Report on Responsible Investing, 2016, https:/www.efama.org/Publications/EFAMA_Responsible\%20Investment\%20Report_September\%202016.pdf (accessed on September 2, 2017).

[5] Ferreira, M.A. and Matos. P. (2008). The Colors of Investors Money: The Role of Institutional Investors around the World, Journal of Financial Economics, 88.3, 499-533.

[6] Ferreira, M.A., Matos. P., Pereira J.P. \& Pires, P. (2017). Do locals know better? A comparison of the performance of local and foreign institutional investors, Journal of Banking and Finance, 82, 151-164.

[7] Gillan, S. L. \& Starks, L. T. (2003). Corporate Governance, Corporate Ownership, and the Role of Institutional Investors: A Global Perspective. Journal of Applied Finance. 13.2, 4-22.

[8] Gurbuz, A.O. Aybars, A. \& Kutlu, O. (2010). Corporate Governance and Financial Performance with a Perspective on Institutional Ownership: Empirical Evidence from Turkey, Journal of Applied Management Accounting Research (JAMAR), 82, 21-37.

[9] Huang, R. Shiu. C. (2005). Overseas Monitors in Emerging Financial Markets: Evidence from Foreign Ownership in Taiwan, University of Notre Dame Working Paper Research

[10] Falkenstein, E. (1996). Preferences for stock characteristics as revealed by mutual fund portfolio holdings, Journal of Finance 51: 111-135.

[11] Kim, J.B. and Yi C.H. (2015). Foreign versus domestic institutional investors in emerging markets: Who contributes more to firm-specific information flow?, China Journal of Accounting Research, 8, 1-23.

[12] Levine, R. and King, R. (1993). Finance, Entrepreneurship and Growth: Theory and Evidence, Journal of Monetary Economics, $32,3,513-542$.

[13] McKinsey Company. Global Investor Survey (2016), http://www.mckinsey.com/clientservice/organiza tionleadership/service/corpgovernance/pdf/ (accessed on September 1, 2017).

[14] Nofsinger, J.R. and Sias, R.W. (1999). Herding and Feedback Trading by Institutional and Individual Investors. The Journal of Finance, 54, 6, 2263- 2295.

[15] Railo, T. (2000). International Diversification in Portfolio Investments of Institutional Investors, International Comparison with Focus in Japan. Working Paper Series.

[16] Turkish Capital Markets Association (TCMA), 2017 Annual Report, https://www.tspb.org.tr/wpcontent/uploads/2015/08/Turkish_Capital_Markets_2016_Annual_Review_opt.pdf (accessed on August 31, 2017).

[17] Zou, L., Tang, T. \& Li, X. 2016. The stock preferences of domestic versus foreign investors :Evidence from Qualified Foreign Institutional Investors(QFIls) in China, The Journal of Multinational Financial Management, 12-28.

[18] http://www.borsaistanbul.com/en/indices/bist-stock-indices/corporate-governanceindex?kufumywsrpldnhfk?xldgtdqeiaynksbt (accessed on August 28, 2017).

[19] http://www.borsaistanbul.com/en/news/2016/10/25/bist-sustainability-index-constituents-for-2016-2017-index-period-havebeen-determined (accessed on August 25, 2017).

[20] https://www.kap.org.tr/tr/Sektorler (accessed on July 10, 2017).

[21] https://portal.mkk.com.tr/portal/(accessed on July 15, 2017). 